Berkeley Law

From the SelectedWorks of Robert Cooter

November, 1974

\title{
Optimal Income Taxation for Transfer Payments Under Different Social Welfare Criteria
}

Robert D. Cooter

Elhanan Helpman, Tel Aviv University 


\title{
OPTIMAL INCOME TAXATION FOR TRANSFER PAYMENTS UNDER DIFFERENT SOCIAL WELFARE CRITERIA *
}

\author{
Robert Cooter Elhanan Helpman
}

I. Introduction, 656. - II. Formulating the problem, 657.-III. Twoperson case, 660. - IV. Simulation of U. S. data, 662. - V. Conclusion, 668. Appendix: data on distribution of abilities, 668 .

\section{Introduction}

Efficiency principles are no guide to optimal tax rates when income redistribution is the purpose of that taxation. Optimal tax rates for redistribution must be obtained through maximization of a social welfare function constrained by technology and by what Pigou called the "announcement effects" of the tax. "Announcement effects" refer to the alterations in the economic behavior of individuals induced by the tax scheme, which appear as constraints upon collective choice because they arise from individual utility-maximizing behavior that society cannot or will not inhibit. When redistribution is accomplished through lump sum transfers, announcement effects are assumed to be nil, and the problem of the distribution branch of government ${ }^{1}$ - equating everyone's marginal social utility of income - is transparent. Mirrlees ${ }^{2}$ has attempted an analytic solution for the optimal income tax by maximizing a utilitarian social welfare function constrained to allow for the incentive effects of the tax upon work effort. Phelps ${ }^{3}$ and Sheshinski ${ }^{4}$ repeated this calculation for the Rawls social welfare function, and Fair ${ }^{5}$ did a similar analysis for a social welfare function written as the product. of individual utilities. This article develops a simulation technique for calculating the optimal income tax under any social welfare

* We wish to thank Professor Richard A. Musgrave for use of unpublished data, for criticism of an early draft of this paper, and for encouragement in revising it. We are also grateful to Professor Robert Dorfman for comments on an early draft of the paper, and to Professors Jerry Green, Martin

1. See R. A. Musgrave, Public Finance (New York: McGraw-Hill, 1959). Taxat. J. A. Mirrlees, "An Exploration in the Theory of Optimum Income 3. E Review of Economic Studies, XXXVIII (April 1971), 175-208.

Journal, LXXXVlps, "Taxation of Wage Income for Economic Justice," this

4. E. Sheshinski, "An Example of Income Tax Schedules Which Are Optimal for the Maxi-Min Criterion," Technical Report No. 74, Institute for Mathematical Studies in the Social Sciences, Stanford University, September
1972 .

5. R. C. Fair, "The Optimal Distribution of Income," this Journal, LXXXV (Nov. 1971), 551-59. 
function whatsoever; calculations are actually made for seven different social welfare functions. We are able to compare optimal marginal taxes under different social welfare functions, and our calculations are higher than those obtained by Mirrlees and Sheshinski. Our technique also allowed us to impute the social welfare function implicit in the actual redistribution accomplished by government in the United States.

\section{Formulating the Problem}

We formulate the problem of optimal income taxation for redistribution as a partial equilibrium analysis in which the wage rate for each individual is fixed. Individuals obtain pretax income by a sacrifice of leisure, and the rate at which an individual can transform leisure into income is determined by his productive skill. We distinguish individuals by their level of productive skill, which is indicated by $n_{i}$ and distributed according to $f\left(n_{i}\right){ }^{6}$ Letting $l=$ proportion of time spent working, we write the pretax income of type- $i$ individual as $y_{i}=n_{i} l_{i}$. His tax bill is $t\left(n_{i} l_{i}\right)$, and his utility is $U\left[n_{i} l_{i}-t\left(n_{i} l_{i}\right), 1-l_{i}\right] .{ }^{7}$ Selecting the optimal tax rate is a matter of choosing $t(\cdot)$ to maximize the social welfare function subject to the constraint that the budget of the redistributing authority is balanced and each individual selects his utility-maximizing combination of leisure and labor:

and

$$
\begin{aligned}
& \max _{i(\cdot)} W\left(U^{1}, \ldots, U^{m}\right) \text { subject to } \\
& \sum_{i=1}^{t} t\left(n_{i} l_{i}\right) f\left(n_{i}\right)=0
\end{aligned}
$$

$$
\begin{aligned}
& \partial U^{i} / \partial l_{i}=0 \text { for } l_{i}>0, \text { for all } i \\
& \partial U^{i} / \partial l_{i} \leqslant 0 \text { for } l_{i}=0 .
\end{aligned}
$$

Increases in the marginal tax rate induce two contradictory effects that are assigned different weight by different social welfare functions. As the marginal tax rate increases, the excess burden due to distortion of the labor-leisure relationship increases for everyone. However, higher tax revenues allow more income to be redistributed to the poor through a subsidy (negative taxation), thus augmenting the income of those whose marginal utility of income is highest. The social optimum occurs where the marginal social cost of an increase

6. $f\left(n_{i}\right)$ is the proportion of individuals with productive skill $n_{i}$, which is a discrete approximation to a continuous distribution.

7. We assume that all individuals have the same utility function in net income and leisure. 
in the burden of higher marginal tax rates just equals the marginal social value of an increase in the subsidy.

If productive skill were a consequence of innate ability and innate ability could be identified, a tax could be levied on productive skill that would be unavoidable and hence nondistorting. The firstbest solution is ability taxation, which requires that the tax authorities know the ability level of each individual. If there is ability taxation, the individual has an incentive to misrepresent his productive skill, which would be an easy thing to do in the upper income brackets. The income tax approach requires that the authorities know the distribution of productive skill but not the skill levels of particular individuals. The income tax approach implicitly assumes that it is more efficient for the tax authorities to distort the work-leisure relationship than provide an incentive for misrepresenting productive
skill.

We solve the optimization problem for seven different social welfare functions, which we name "Rawls," "Elitist," "Bentham," "Nash," "Egalitarian," Democratic," and "max GNP." The Rawls point is located where the utility of the individual whose ability is least attains its maximum, ${ }^{8}$ and the Elitist point maximizes the utility of the most able. ${ }^{9}$ The Bentham point occurs where the unweighted sum of utilities is greatest, and the Nash point maximizes their unweighted product. The Democratic criterion maximizes the utility of the class of median ability. The Egalitarian point minimizes the Gini coefficient defined on net income, and the max GNP maximizes the average income level. The latter two social welfare functions are not written over final utilities, but are useful for characterizing the efficiency-equality trade-off.

These specifications of the social welfare function place bounds upon the solution to the optimization problem. The Rawls criterion implies that returns to scale diminish so rapidly that only the lowest utility group need be considered; the Elitist criterion implies that returns to scale increase so rapidly that only the highest utility group need be considered; the Bentham and Nash points represent intermediate cases. If the individual were in the "original position" 8. See J. Rawls, A Theory of Justice (Cambridge, Massachusetts: Har-
vard University Press, 1971). 9. In this model there is a perfect correlation between the ranking of in-
dividuals by utility and productive skill. When only income is taxed, a person
of higher ability can always obtain at least as much utility a of higher ability can always obtain at least as much utility as a person of lower a smaller proportion of same income and paying the same tax but working a smaller proportion of the time. The exception to this generalization is that
in every ability class obtaining prevents anyone from working at all, will result in every ability class obtaining the same utility level, since all utility is from
leisure. 
of social contract theory, ${ }^{10}$ where he is ignorant of his own productive skill, expected utility maximization would compel him to pick the tax-subsidy schedule that maximizes the unweighted sum of utilities. ${ }^{11} \mathrm{He}$ would choose the Rawls, Bentham, Nash, or Elitist point - or some point in between - depending upon his risk preferences. $^{12}$ One may use social contract theory to argue for the moral superiority of one social welfare function over another, but theories of self-interested choice need not predict that individuals will do what is moral. The median voting rule predicts that the Democratic social welfare function will be maximized in the actual government redistribution activity if tax rates are set by majority voting over paired alternatives, assuming that preferences are singlepeaked. ${ }^{13}$

Solution of the maximization problem as we formulated it becomes possible once one specifies manageable functional forms for the utility function and the tax function. We experimented with a variety of such forms but found a CES utility function ${ }^{14}$ and a linear tax function most flexible per computational dollar. ${ }^{15}$ The linear tax function, written as $\left(t\left(y_{i}\right)=-A+B y_{i}\right.$, provides for a fixed income transfer paid to everyone, which is the usual formulation of the negative income tax proposal. ${ }^{16}$

10. See Rawls, op. cit.

11. See W. S. Vickrey, "Utility, Strategy, and Social Decision Rules," this Journal, LXXIV (Nov. 1960), 507-35.

12. See K. J. Arrow, "Some Ordinalist-Utilitarian Notes on Rawls' Theory of Justice," Journal of Philosophy, LXX (May 10, 1973), 245-63, for a discussion of this point.

13. See D. Black, Theory of Committees and Elections (Cambridge: Cambridge Press, 1958). The median voter's income class may differ somewhat from what a frequency distribution suggests because rates of voter registration and participation are not independent of income class.

14. We use a constant returns to scale utility function for the following reason: Any monotonic transformation of the individual utility function will not influence the labor-leisure choice, but will affect the weights by which utilities are combined in the social welfare function. Since the role of the social welfare function is to impose a conception of economic justice upon the distribution of observed utilities, we assume constant returns to scale for individual utility functions and leave the social welfare function to determine the appropriate weights for combining them. The labor-leisure combinations admitted by the analysis are circumscribed by the linear homogeneity of the Engel curves for the CES utility function.

15. For example, experiments with the nonlinear tax function, $t\left(y_{i}\right)=y_{i}-a\left(y_{i}\right)^{b}$,

showed that the utility frontier in the two-person case was dominated by the linear tax function $t\left(y_{i}\right)=-a+b y_{i}$.

16. Musgrave's calculation of actual redistributive behavior of government in the United States (in R. A. Musgrave and P. B. Musgrave, Public Finance in Theory and Practice; New York: McGraw-Hill, 1973) fitted a linear tax function almost perfectly (See Section IV for details on this point). Using a linear tax function to solve the optimization problem enabled us therefore to impute the social welfare function implicit in actual redistribution activity. 


\section{Two-Person Case}

The conceptual problem is clarified by examining the twoperson case, which contains most of the features of the simulation on actual U. S. data. If the tax function is linear, $t\left(y_{1}\right)=-A+B y_{i}$, and the utility function is Cobb-Douglas,

$$
U^{i}=\left(n_{i} l_{i}+A-B n_{i} l_{i}\right)^{g}\left(1-l_{i}\right)^{1-g},
$$

then the balanced budget constraint and the individual utility-maximizing quantity of labor may be written as

and

$$
A=0.5 B\left(n_{1} l_{1}+n_{2} l_{2}\right)
$$

$$
l^{*}{ }_{i}=g+A(g-1) / n_{i}(1-B) \text { for } i=1.2 .
$$

Once the tax parameter $B$ is given and the ability levels are known, we can solve immediately for $l^{*}{ }_{i}$ and $U^{i}$. We wrote a computer program that solved for $U^{1}$ and $U^{2}$ and varied $B$ from 0.0 to 0.9 , and thus we identified the utility frontier for positive $B$ 's. The utility frontier is shown in Figure I for the case where $g=1 / 2$ and the

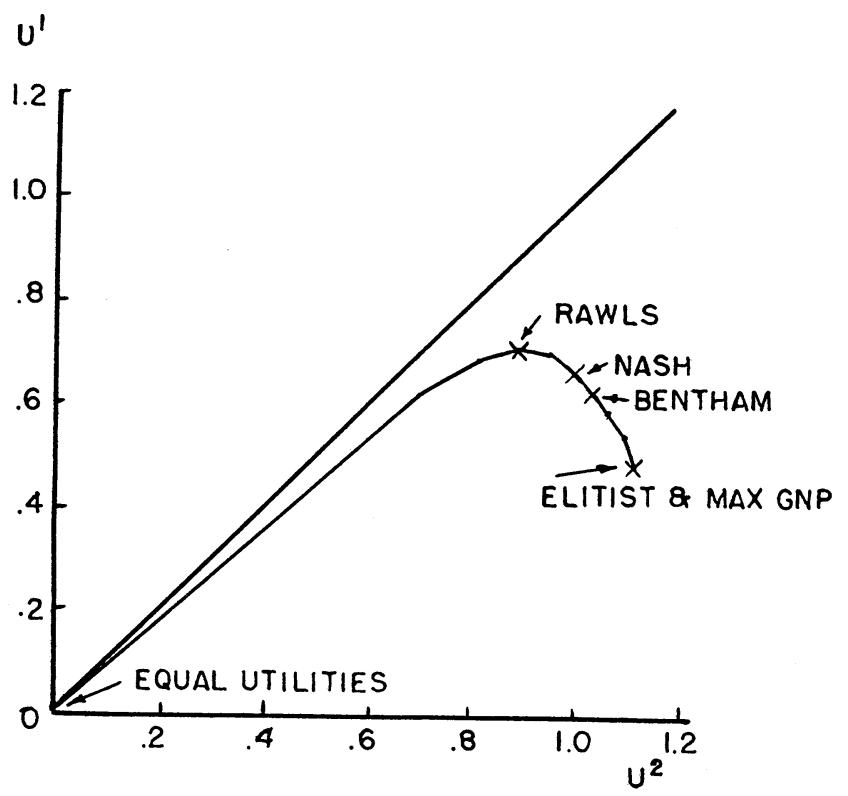

Figure I

$g=5$; highest ability $=5$; lowest ability $=1$.

It is also interesting to note that Mirrlees (op. cit.) found that the optimal tax function under the utilitarian social welfare function was almost linear. 
ability levels of the two individuals are $n_{1}=1$ and $n_{2}=5$. The points on the frontier that are optima under the various social welfare functions are labeled.

Table I shows how the optimal marginal tax rate varied for

TABLE I*

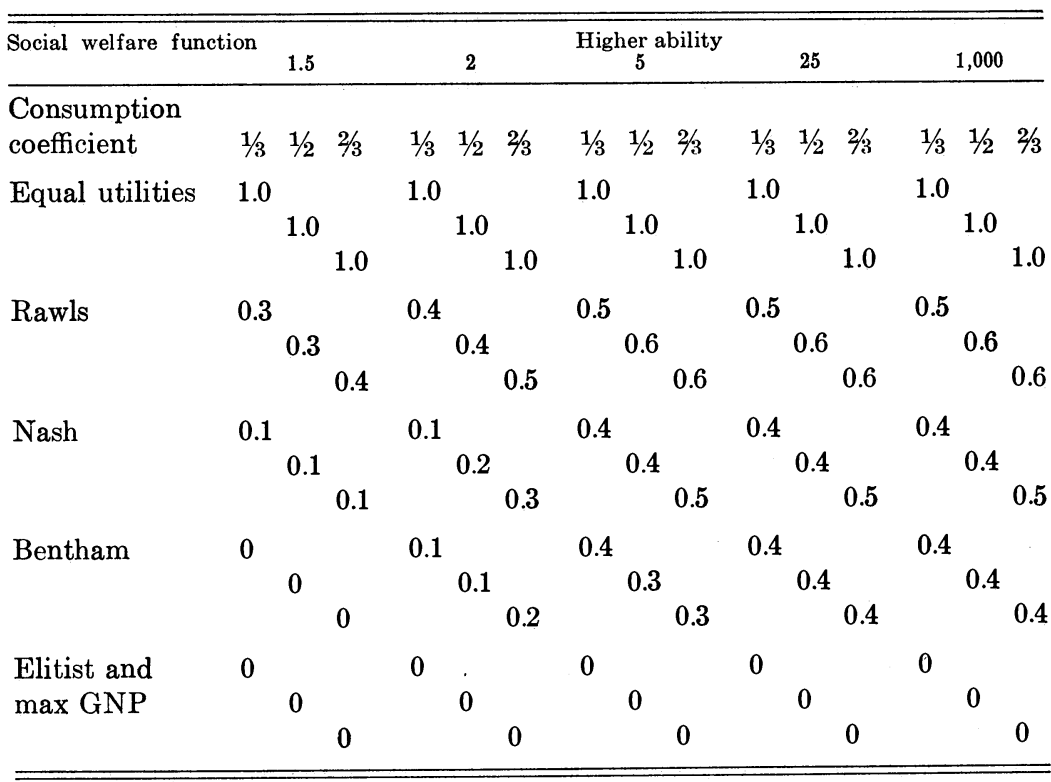

* The ability level of the lower ability individual is set at one.

each social welfare function in the two-person case as the highest ability level and the exponent on consumption $(g)$ increased. ${ }^{17} \mathrm{We}$ can make two generalizations from the two-person case that apply to U. S. data: (1) Social welfare functions typically preserved their rank by size of the optimal marginal tax rate as the distribution of ability changed or as the parameters of the utility function changed. The ranking from high to low was typically Rawls $\geqq N a s h \geqq$ Bentham $\geqq$ Elitist, (2) The optimal marginal tax rate was at least as high under a less equal distribution of skill as under a more equal one, regardless of which social welfare function was chosen. The first generalization suggests that Mirrlees would have found higher marginal tax rates if he had used some social welfare function different from the Bentham criterion in making his calculations. The second generalization implies that those who believe productive skills are unevenly distributed ought to favor higher tax rates under any

17. The lower ability level equals 1 and is kept constant. 
TABLE II

Optimal Taxes Under Three Assumptions About Productive Skill * A. Skill Distributed as Pregovernment Income



particular social welfare function than someone else who believes that productive skills are more equally distributed.

\section{Simulation on U. S. Data}

There seems to be no strictly correct assumption about the distribution of productive skills so we proceeded by a sensitivity analysis. One extreme assumption is that productive skill is distributed with a skew to the right like income prior to government redistribution activity. Musgrave has estimated the redistributive impact of federal, state, and local government taxation and expenditure, so we used his data to estimate what the distribution of income would be without such activity. Our other extreme assumption is that productive skill has a tight normal distribution, as suggested by some tests of basic ability (e.g., IQ). Our moderate assumption 
B. Skill Distributed Normally

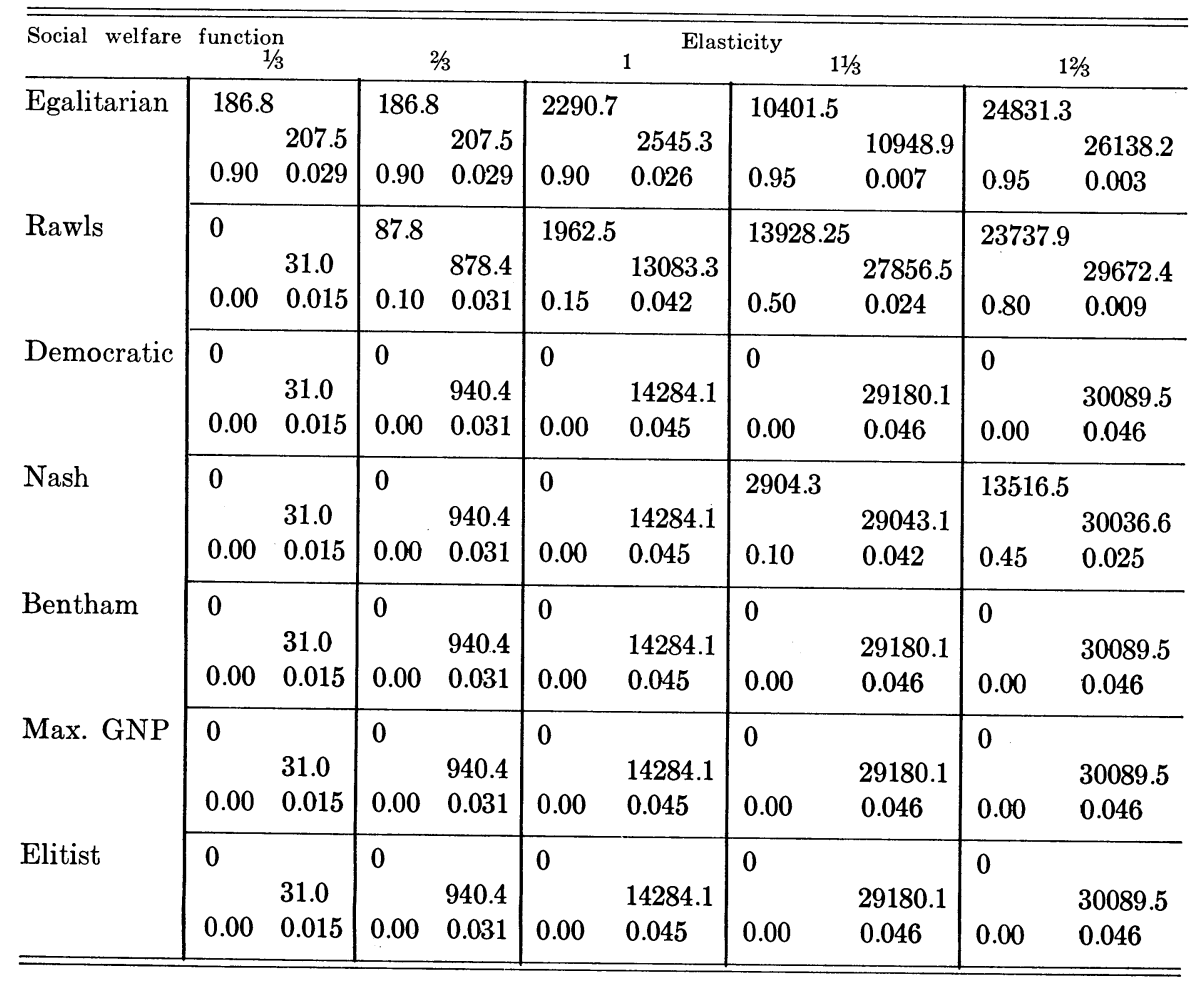

is that ability is distributed as wages per hour worked, for which we obtained data from a study by Hall. ${ }^{18}$

The simulation was made for elasticities of substitution varying from 0.1 to 2.0 , and for coefficients on consumption varying from 0.1 to $0.9 .^{19}$ Extreme values of the elasticity of substitution and the consumption coefficient gave results for which the average income of each bracket or the hours worked exceeded sensible limits. Results are reported in Table II for five different elasticities of substi-

18. See R. E. Hall, "Wages, Income, and Hours of Work in the U. S. Labor Force," in H. Watts and G. Cain, eds., Labor Supply (Chicago: Markham, 1974).

See Appendix for details concerning our three assumptions about the distribution of ability.

19. The explicit form of the utility function is

$$
\begin{aligned}
& U\left(c_{i}, 1-l_{i}\right)=\left[a c_{i} \frac{\sigma-1}{\sigma}+(1-a)\left(1-l_{i}\right) \frac{\sigma-1}{\sigma}\right] \frac{\sigma}{\sigma-1} \\
& \sigma=\text { elasticity of substitution } \\
& a=\text { consumption coefficient } \\
& c_{i}=\text { consumption of an individual of type } i \text { (equals his net income) } \\
& l_{i}=\text { leisure of an individual of type } i .
\end{aligned}
$$


C. Skill Distributed as Wage Per Hour

\begin{tabular}{|c|c|c|c|c|c|c|c|c|c|c|}
\hline \multicolumn{3}{|c|}{ Social welfare function } & \multicolumn{2}{|c|}{$2 / 3$} & \multicolumn{4}{|c|}{$\begin{array}{ll}\text { Elasticity } & \\
11 / 3\end{array}$} & \multicolumn{2}{|c|}{$12 / 3$} \\
\hline Egalitarian & & & $\begin{array}{l}244.1 \\
0.70\end{array}$ & $\begin{array}{l}348.8 \\
0.098\end{array}$ & $\begin{array}{l}3132.2 \\
0.75\end{array}$ & $\begin{array}{l}4179.0 \\
0.097\end{array}$ & $\begin{array}{l}11350 . \\
0.90\end{array}$ & $\begin{array}{l}9 \\
12612.2 \\
0.029\end{array}$ & $\begin{array}{l}17844.6 \\
0.95\end{array}$ & $\begin{array}{l}18783.7 \\
0.010\end{array}$ \\
\hline Rawls & $\begin{array}{l}6.3 \\
0.25\end{array}$ & $\begin{array}{l}25.3 \\
0.050\end{array}$ & $\begin{array}{l}243.6 \\
0.50\end{array}$ & $\begin{array}{l}487.1 \\
0.100\end{array}$ & $\begin{array}{l}3502.7 \\
0.50\end{array}$ & $\begin{array}{l}7005.5 \\
0.115\end{array}$ & $\begin{array}{l}13298 . \\
0.70\end{array}$ & $\begin{array}{l}18997.7 \\
0.053\end{array}$ & $\begin{array}{l}18465.1 \\
0.85\end{array}$ & $\begin{array}{l}21723.6 \\
0.024\end{array}$ \\
\hline Democratic & $\begin{array}{l}0 \\
0.00\end{array}$ & $\begin{array}{l}27.8 \\
0.050\end{array}$ & $\begin{array}{l}36.9 \\
0.50\end{array}$ & $\begin{array}{l}738.5 \\
0.102\end{array}$ & $\begin{array}{l}1005.2 \\
0.10\end{array}$ & $\begin{array}{l}10051.9 \\
0.144\end{array}$ & $\begin{array}{l}7370.3 \\
0.35\end{array}$ & $\begin{array}{l}21057.9 \\
0.103\end{array}$ & $\begin{array}{l}15523.4 \\
0.70\end{array}$ & $\begin{array}{l} \\
22176.3 \\
0.046\end{array}$ \\
\hline Nash & $\begin{array}{l}0 \\
0.00\end{array}$ & $\begin{array}{l}27.8 \\
0.050\end{array}$ & $\begin{array}{l}71.3 \\
0.10 \\
\end{array}$ & $\begin{array}{l}713.2 \\
0.102\end{array}$ & $\begin{array}{l}1005.2 \\
0.10\end{array}$ & $\begin{array}{l}10051.9 \\
0.144\end{array}$ & $\begin{array}{l}7370.3 \\
0.35\end{array}$ & $\begin{array}{l}21057.9 \\
0.103\end{array}$ & $\begin{array}{l}14445.9 \\
0.65\end{array}$ & $\begin{array}{l}22224.5 \\
0.054\end{array}$ \\
\hline Bentham & $\begin{array}{l}0 \\
0.00\end{array}$ & $\begin{array}{l}27.8 \\
0.050\end{array}$ & $\begin{array}{l}36.9 \\
0.05\end{array}$ & $\begin{array}{l}738.5 \\
0.102\end{array}$ & $\begin{array}{l}517.5 \\
0.05\end{array}$ & $\begin{array}{l}10349.1 \\
0.147\end{array}$ & $\begin{array}{l}1078.6 \\
0.05\end{array}$ & $\begin{array}{l}21572.3 \\
0.146\end{array}$ & $\begin{array}{l}1117.9 \\
0.05\end{array}$ & $\begin{array}{l}22358.3 \\
0.144\end{array}$ \\
\hline Max. GNP & 0.00 & $\begin{array}{l}27.8 \\
0.050\end{array}$ & $\begin{array}{l}0 \\
0.00\end{array}$ & $\begin{array}{l}763.3 \\
0.102\end{array}$ & $\begin{array}{l}0 \\
0.00\end{array}$ & $\begin{array}{l}10632.0 \\
0.151\end{array}$ & $\begin{array}{l}0 \\
0.00\end{array}$ & $\begin{array}{l}21625.3 \\
0.153\end{array}$ & $\begin{array}{l}0 \\
0.00\end{array}$ & $\begin{array}{l}22360.8 \\
0.152\end{array}$ \\
\hline Elitist & $\begin{array}{l}0 \\
0.00\end{array}$ & $\begin{array}{l}27.8 \\
0.050\end{array}$ & $\begin{array}{l}0 \\
0.00\end{array}$ & $\begin{array}{l}763.3 \\
0.102\end{array}$ & $\begin{array}{l}0 \\
0.00\end{array}$ & $\begin{array}{l}10632.0 \\
0.151\end{array}$ & $\begin{array}{l}0 \\
0.00\end{array}$ & $\begin{array}{l}21625.3 \\
0.153\end{array}$ & $\begin{array}{l}0 \\
0.00\end{array}$ & $\begin{array}{l}22360.8 \\
0.152\end{array}$ \\
\hline
\end{tabular}

*The upper left corner presents the optimal fixed transfer in dollars.

The upper right corner presents income per capita in dollars.

The lower left corner presents the optimal marginal tax.

The lower right corner presents the Gini coefficient.

tween 0.05 and 0.95 . Tax rates varying beperson case.

tution, but the consumption coefficient is one half throughout this table. The two generalizations obtained in the two-person case are seen to apply to this table: the ranking of the social welfare functions defined over final utilities is preserved as the parameters of the utility function and ability distribution change, and a more unequal distribution of skills implies at least as high an optimal marginal tax rate under any particular social welfare function as a less unequal distribution. The behavior of the optimal marginal tax rate under a given social welfare function is not monotonic with the elasticity of substitution, as can be seen in Figure II.

In Figure III we observe that there is a trade-off between GNP and equality as measured by the Gini coefficient in the case where ability is distributed normally. For example, moving from the 


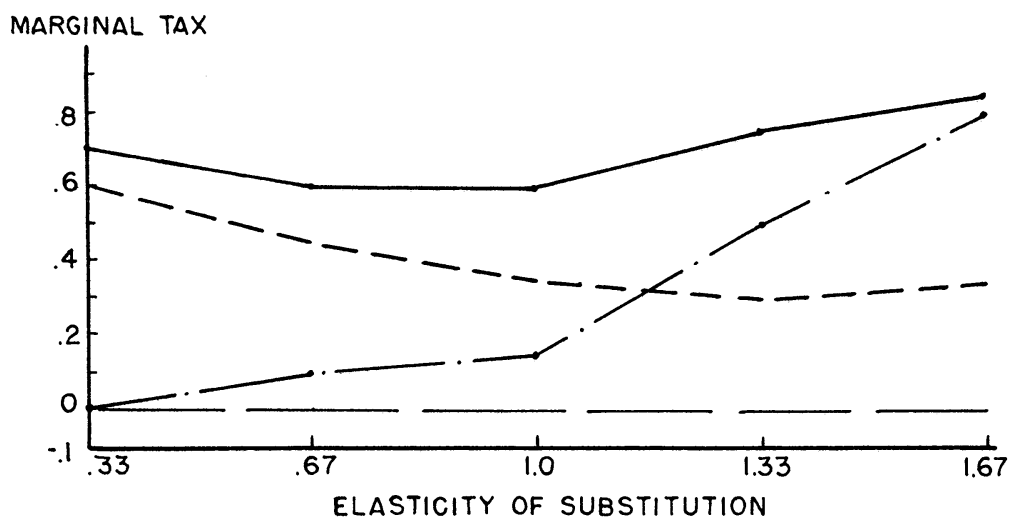

FIGURE II

The solid line is the Rawls criterion using pregovernment income distribution for abilities. The line composed of short dashes is the Bentham criterion using pregovernment income distribution for abilities. The line composed of long dashes is the Rawls criterion using normal income distribution for abilities. The double line is the Bentham criterion using normal income distribution for abilities.

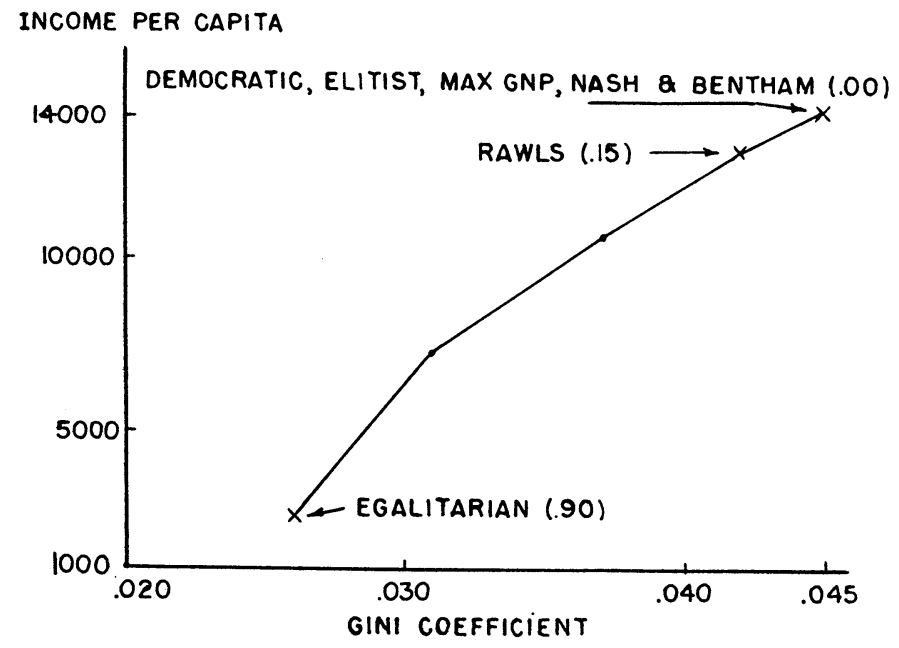

FIGURE III

Ability distributed normally. Elasticity $=1$.

Bentham point to the Rawls point results in a decline in the Gini coefficient and a fall in income per capita. However, this trade-off breaks down when the elasticity of substitution is less than 1 and ability is distributed as pregovernment income, as can be seen in 
Figures IV and V. For example, in Figure IV the Rawls point has a higher Gini coefficient and a lower GNP than the Bentham point. A curious feature of Figure $\mathrm{V}$ is that GNP is maximized when the

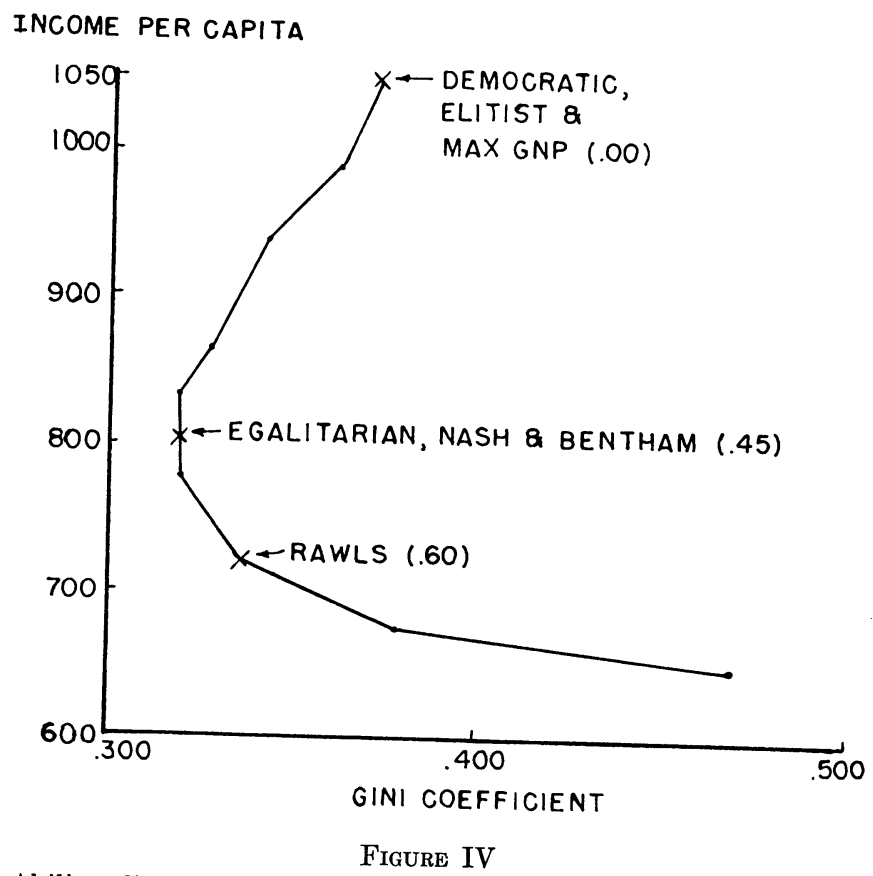

Ability distributed as pregovernment income. Elasticity $=2 / 3$.

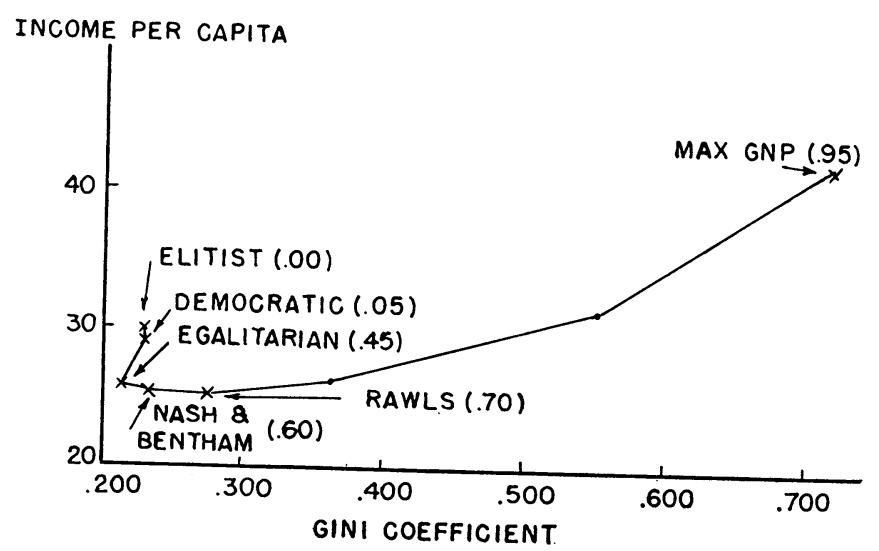

Figure V

Ability distributed as pregovernment income. Elasticity $=1 / 3$. Numbers in brackets indicate the optimal marginal tax rate. 
marginal tax rate is set at 0.95 ! This can be explained by the fact that with low elasticity and ability distributed as pregovernment income the more able persons increased work as the marginal tax rose. Apparently one's intuition is not always a good predictor of actual outcomes in this model.

Musgrave (see Appendix) estimated the effect of government redistribution activity under a best assumption and under an assumption most favorable to tax and expenditure progressivity. By regressing his estimate of postgovernment income upon pregovernment income, one obtains an estimate of total government redistributive activity according to our model $t\left(y_{i}\right)=-A+B y_{i}$, where $y_{i}$ is one of ten income brackets. The results of GLS for Musgrave's best assumption and most progressive assumption were

$$
t\left(y_{i}\right)=-1623+0.12 y_{i} \text { (best assumption) }
$$

and

$$
t\left(y_{i}\right)=-7781+0.57 y_{i} \text { (most progressive assumption). }
$$

We impute the social welfare function by determining which of our seven social welfare functions requires a marginal tax rate close to that found in the equations above. We eliminate all cases where the optimal solution requires a marginal tax rate that differs from the estimated one by more than $= \pm 0.15$ or a fixed transfer that differs from the estimated one by more than $= \pm \$ 1,650$. We also eliminate from consideration all cases in which the resulting average family income and share of time worked (in the optimal solution) fall outside the limits $\$ 10,000-\$ 25,000$ and $0.2-0.5$, respectively.

The implicit social welfare functions under each of the assumptions about the distribution of productive skills that passed both tests are given in Table III. Caution should be exercised in applying these results because of the substantial margin of error in their calculation, but the fact that the implicit social welfare function is Democratic under Musgrave's best assumption on distributional

TABLE III *

\begin{tabular}{lll}
\hline \hline Ability distribution & Best assumption & Extreme assumption \\
\hline \multirow{3}{*}{ Pregovernment } & Elitist & Egalitarian \\
& Max. GNP & Rawls \\
Normal & Democratic & \\
Wages & Rawls & none \\
\hline \hline
\end{tabular}

* We refer to the estimates of the actual government redistribution under Musgrave's "best" and "most progressive" assumptions. 
effect of government activity and the assumption that ability is distributed as wages per hour - perhaps the best assumption on distribution of ability - vindicates the median rule. ${ }^{20}$

\section{Conclusion}

The distributive branch of government must calculate the income tax for optimal redistribution by maximizing a social welfare function constrained by technology and the announcement effects of the tax. A partial equilibrium analysis that takes into account the announcement effect upon work effort ${ }^{21}$ shows that the marginal tax rate that is optimal for any particular social welfare function increases with inequality in the distribution of productive skill. The ranking of social welfare functions by size of optimal marginal tax rate was Rawls $\geqslant$ Nash $\geqslant$ Bentham $\geqslant$ Elitist, regardless of the distribution of productive skill or the elasticity of substitution. The inverse of this ranking did not always correspond to the ranking of social welfare functions by the size of the Gini coefficient. The social welfare function implicit in actual U. S. government transfer activity under Musgrave's best assumption and the intermediate ability distribution was Democratic, as predicted by the median rule.

\section{Appendix: Data on Distribution of Abilities}

Musgrave established ten money factor income brackets and used data obtained from the Brookings Institution and the Census Bureau to calculate the proportion of families and unrelated individuals falling into each bracket. (First row of Table IV). Nonmonetary income (primarily unrealized capital gains) was then imputed to each bracket under several different assumptions. All federal, state, and local government taxation and expenditure was distributed to the various income brackets under several assumptions. The result gave the pregovernment income and postgovernment income for each bracket, which appears in rows 2,3 , and 4 in Table IV. ${ }^{22}$ From the Musgrave calculations we selected the

20. Substantial differences in optimal marginal tax rates under the Democratic and Rawls criteria are indicative of a conflict of interest between low-

21. A general analysis would take account of the effect of taxation upon savings, capital formation, and the distribution of productive skill.

22. The data in Table IV in the Appendix are obtained by a minor transformation of data found in row 1 of table 2 , rows 40 and 42 of Table 7 , and rows 53 and 54 of Table 14 of R. A. Musgrave, Karl E; Case, and Herman sion Paper No. 319, September 1973. A complete discuts," H. I. E. R. Discussumptions is found there. A more 1973 . A complete discussion of incidence asMusgrave and Musgrave, op. cit. 
TABLE IV

Musgrave's Data and the Appropriate Normal Distribution

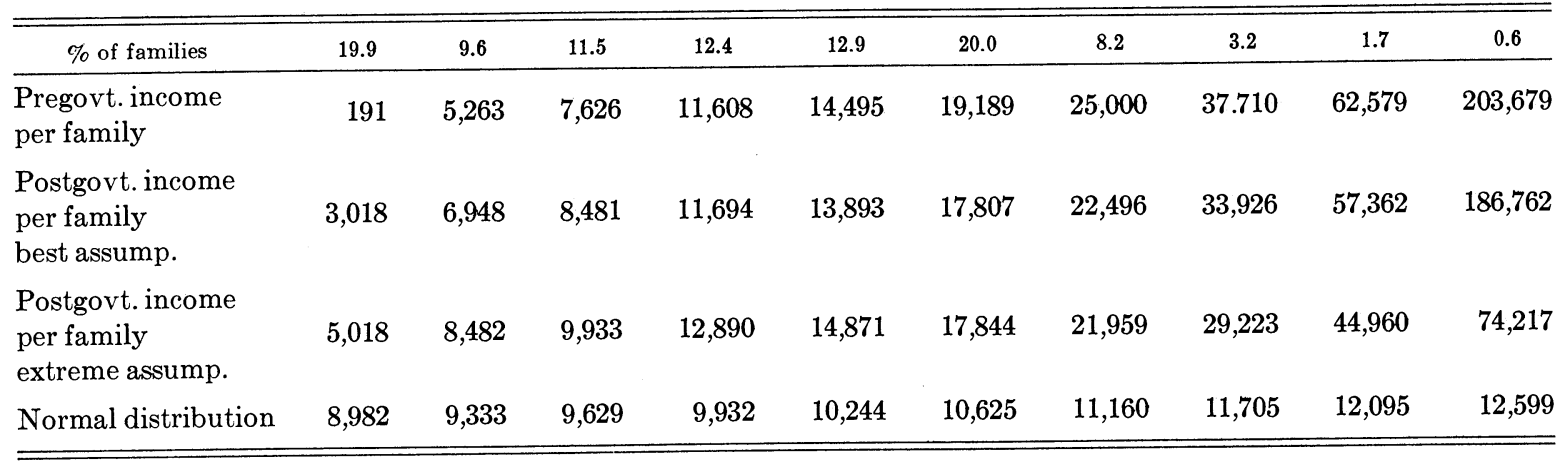


assumptions that most increased the skew in pregovernment income to obtain row 2 in Table IV. Postgovernment income for each of the ten brackets was used in the regressions reported on page 667 .

For the normal distribution we used a truncated distribution with mean of $\$ 10,000$ and standard deviation of $\$ 1,000$, from which we calculated the average income in each of the percentage brackets. The results are given in row 5 of Table IV.

Robert Hall obtained his data on wage per hour from the SEO sample, and they are reproduced as Table V. ${ }^{23}$ All the data on the

TABLE $\mathrm{V}$

Robert HaLl's Data

\begin{tabular}{|c|c|c|c|c|c|c|c|}
\hline \multicolumn{4}{|c|}{ MALE } & \multicolumn{4}{|c|}{ FEMALE } \\
\hline $\begin{array}{c}\# \text { of } \\
\text { persons }\end{array}$ & $\begin{array}{c}\begin{array}{c}\text { Wage } \\
\text { per hour }\end{array} \\
\text {. }\end{array}$ & $\begin{array}{c}\# \text { of } \\
\text { persons }\end{array}$ & $\begin{array}{l}\text { Wage } \\
\text { per hour }\end{array}$ & $\begin{array}{c}\# \text { of } \\
\text { persons }\end{array}$ & $\begin{array}{c}\text { Wage } \\
\text { per hour }\end{array}$ & $\begin{array}{c}\# \text { of } \\
\text { persons }\end{array}$ & $\begin{array}{c}\text { Wage } \\
\text { per hour }\end{array}$ \\
\hline 58 & 2.16 & 102 & 2.03 & 23 & 1.77 & 43 & 1.42 \\
\hline 153 & 2.39 & 234 & 2.11 & 58 & 1.67 & 133 & 1.59 \\
\hline 578 & 2.62 & 560 & 2.17 & 289 & 1.80 & 405 & 1.60 \\
\hline 452 & 2.89 & 446 & 2.23 & 248 & 1.99 & 351 & 1.70 \\
\hline 932 & 3.16 & 556 & 2.45 & 744 & 2.27 & 622 & 2.03 \\
\hline 343 & 3.49 & 168 & 2.73 & 213 & 2.55 & 176 & 2.43 \\
\hline 84 & 3.61 & 33 & 2.92 & 44 & 2.65 & 18 & 2.72 \\
\hline 249 & 4.65 & 57 & 3.16 & 135 & 3.11 & 64 & 3.50 \\
\hline 233 & 4.36 & 38 & 4.47 & 82 & 3.49 & 46 & 4.44 \\
\hline
\end{tabular}

distribution of skill were adjusted to reflect the ability to earn if a person works 365 days per year, twenty-four hours per day. For the normal and pregovernment distribution we assumed that the data reflect actual working time of 33 percent of the available
time.

HARVARD UnIVERSITY

23. Hall, op. cit., Tables A2-1 and A2-2. 